\title{
The greenest government ever? The Coalition Government and low-carbon policy
}

\author{
Aidan While* \\ University of Sheffield
}

\begin{abstract}
In 2010 David Cameron pledged that he would lead the 'greenest government ever'. In practice environmental policy has been pulled in different directions by competing factions and the hollowing out of environmental governance through deregulation and deficit reduction. This is particularly evident in low-carbon policy which has been strengthened as well as weakened under the Coalition Government. The following contribution unpicks the twists and turns of low-carbon policy since 2010 and reflects on the future direction of travel in this key area of public policy.
\end{abstract}

Keywords: Coalition government, low-carbon, policy, environment.

\section{Introduction}

In the heady days after the 2010 Coalition Agreement David Cameron pledged that this would be the 'greenest government ever' (Randerson, 2010). The environment seemed to be a personal interest of a new Prime Minister who had made climate change visits to the Arctic, cycled to work and added a wind turbine to his North London home. Initial enthusiasm for environmental policy also resonated with the new direction being pushed for the Conservative Party, symbolised by its new green tree logo (Porritt, 2011: 3). The government was formed with a Liberal Democrat party that had a strong track record on the environment and a firm promise in its manifesto to integrate the environment into all policy areas. The Chancellor-to-be George Osborne appeared to have bought into the idea of a sustainable green economy, setting out plans in opposition for a Green Investment Bank to help drive green infrastructure investment and promising that the Treasury would be 'a green ally, not a foe'. As Jonathon Porritt (2011) wrote, "there is not a priori reason (practical or ideological) why a Conservative Government (let alone a Conservative/Lib Dem Coalition)" should not be the greenest ever.

Writing in this journal's pre-election issue on public policy at the crossroads, lan Rotherham (2010) warned that significant resources were needed to fulfil national environmental commitments, posing challenges for whatever government came into power. If anything his review underestimated the massive costs of upgrading the UK 
energy infrastructure, let alone the scale of austerity cuts under the Coalition Government. Nevertheless environmental commitments ran through the Coalition Agreement and into the early business plans of key government ministries, including the Treasury. George Osborne announced $£ 3$ billion of support for the Green Investment Bank, there were plans to introduce a carbon floor price to take up the slack of the EU Emissions Trading Scheme, and key government departments would work together to publish a Green Economy Roadmap amongst other policy commitments (Porritt, 2011). By 2010 the growing Low Carbon Environmental Goods and Services sector offered significant potential for further growth and job creation provided there was sufficient investment and policy support from central government. In what seemed to be a clear statement of future intent the Government refused BAA's third runway at Heathrow Airport and banned new runways at Gatwick or Stansted up to 2020 .

However cracks were already starting to appear by the end of the Coalition Government's first year in office as green commitments were squeezed by austerity and deficit reduction (Porritt, 2011). Suggestions of a green stimulus were subsequently to give way to a desperate search for economic recovery, with environmental policy increasingly portrayed as a constraint on business. Environmental commitments were further threatened by staunch opposition to renewable energy within the Conservative Party and a relentless campaign to roll-back and weaken environmental regulation. For example, in the 2011 Autumn Statement, George Osborne singled out green policies as a 'burden' and a 'ridiculous cost' to British business, arguing that 'if we burden [British businesses] with endless social and environmental goals - however worthy in their own right - then not only will we not achieve those goals, but the businesses will fail, jobs will be lost, and our country will be poorer' (Harvey, 2011). The scene was set for growing tension around the principles of environmental management. These tensions can be traced in various policy areas (see Goodchild and Hammond on planning in this issue). The following contribution examines the direction of travel in carbon regulation and energy policy.

\section{Still at the crossroads: the stalling of low-carbon policy}

By 2010 a coordinated national decarbonisation framework was beginning to take shape. The Labour government left a strong legacy of low-carbon policy including mandatory reduction targets in the 2008 Climate Change Act, a new Department for Energy and Climate Change and various initiatives to drive change. The Carbon Emissions Reduction Target (CERT) programme offered free or discounted insulation funded through a levy on energy bills, a generous Feed in Tariff scheme was finally introduced in April 2010, and new housing would have to meet stringent zero carbon standards by 2016. It was recognised that decarbonisation was a matter of economic competitiveness and social resilience linked to concerns about energy security as much as climate change (While et al., 2010; Ellis et al., 2013: 399).

The Climate Change Act is not only still on the books, but in 2011 ministers agreed to push the pace of change by requiring a 50 per cent change on 1990 levels by the mid-2020s. DECC has also launched the world's first Renewable Heat Incentive, underwritten by $£ 860$ million of government subsidies to increase investment in decentralised heat technologies and by $£ 4.5$ billion by 2020 (Porritt, 2011). Inherited commitments to feed-in tariffs and zero carbon construction (for new homes by 2016 and commercial buildings by 2019) have been retained and $£ 400 m$ of subsidy and investment has been allocated to increase the uptake of ultra low emission vehicles (DfT, 2013). The Coalition Government has followed through on the pledge to establish a carbon floor price rising from $£ 15.70 /$ tonne CO2e in 2013 to $£ 70 /$ tonne CO2e in 
2030 even though this could lead to significantly higher energy costs than other EU countries. It could be argued that in some respects low-carbon policy has moved on considerably since 2010.

However the coherence of climate policy and the pace of change have been undermined by increasing opposition within Government, especially following Chris Huhne's resignation as Secretary of State for Energy and Climate Change in early 2012. Anti-renewable factions in the Conservative Party have since come to the fore, subsidies have been cut back, and regulation has been watered down to make life easier for business. Conservative Party resistance to wind turbines has restricted onshore renewables and disagreements within the coalition led to delays in regulations for zero carbon housing and concerns that they will be watered down because of lobbying from housebuilders. Meanwhile ministers have sought to 'end the war on motorists' and George Osborne has ensured a potential opt-out on the 2011 carbon reduction agreement if there is evidence that Britain is moving faster than the rest of the EU. The Coalition Government is closely monitoring the 'competitiveness risks' of its low-carbon regulation (CCC, 2013).

Environmental grants and subsidies have been scaled back under the Coalition Government. Feed-in tariffs (FiTs) for solar power have been cut from $43 p$ to $16 p$ for each kilowatt hour of electricity generated, with payments over 20 years instead of the previous 25 years. However this is perhaps best seen as a sensible adjustment to an overly generous scheme that benefited middle-class homeowners; even with the subsidy cut solar panels still offer a good return on investment of around 9-10 per cent and other countries such as Germany have made similar reductions (Harvey, 2012). The introduction of a new energy efficiency policy regime in the form of the Green Deal and Energy Company Obligation (ECO) might be seen less favourably.

The aim of the Green Deal is to make a step-change in carbon reductions across the UK housing stock - 'a revolution in British property' (DECC, 2011: 10). It represents a substantial change from the existing policy regime in a number of ways, but particularly the move from public subsidy (an obligation on energy companies to supply energy saving measures financed from energy bills) to a privately financed loan scheme tied to the building and paid back through energy bills. The Green Deal is also intended to finance more expensive energy efficiency measures than was previously the case. Yet the Treasury's insistence that loans should be offered at commercial rates of interest (around seven per cent) has made the scheme unattractive and limited what can be funded. The scheme also underestimates the importance of non-financial barriers to household retrofitting. There are also concerns that landlords will have little incentive to use the Green Deal, thus excluding just over 15 per cent of the total housing stock (CRESR, 2013). From April 2016 landlords will have to meet requests from tenants for 'reasonable' energy efficiency improvements. By 2018 all privately rented domestic properties should be brought up to minimum energy performance rating of band $\mathrm{E}$, but enforcement is likely to be a significant challenge even without cuts in local government spending (Eadson, Gilbertson and Walshaw, 2013).

Take-up of Green Deal loans has so far been low and delays in setting up the programme have led to drastic cuts in household investment, with cashback incentives mainly used for boiler replacements (Shankleman, 2013). Rosenow and Eyre (2012) suggest that the Green Deal might only deliver a quarter of the carbon reduction previous schemes. There is projected to be a major reduction in the rate of key low cost insulation measures such as loft insulation with negative implications for both carbon reduction and the insulation industry.

Changes in energy efficiency support have important implications for the overlap between social and environmental policy. Over the last decade fuel poverty has 
increased significantly in the UK rising to over 4.75 million households in 2010 (DECC, 2013). This is due in part to rising energy prices which will continue to rise over the next decade to cover the costs of decarbonisation. Pre-2010 policy included a range of schemes that were starting to make inroads on fuel poverty despite the recession (DECC, 2013). Fuel poverty policy included Warm Front grants for insulation and heating and specific targets for low income households and areas in the Carbon Emissions Reduction Target (CERT) and Carbon Energy Savings Obligation. In 2012 those schemes were replaced by a combination of the Green Deal and Energy Company Obligation (ECO). The limitations of the Green Deal have already been covered. Unless loans can be offered at much lower rates of the Green Deal is unlikely to offer much for those on low-incomes. The ECO is intended to fill the gap by carrying forward previous obligations on energy companies to deliver energy efficiency measures and affordable warmth to deprived communities and low income households (DECC, 2012b). The problem is that overall funding to alleviate fuel poverty is being cut by around 29 per cent (ACE, 2012). There are also concerns that the proposals for ECO mark a risky shift from low-cost insulation to higher cost energy saving measures. In the short-term, the shift from one funding regime to another has led to a sharp drop in uptake by fuel poor households. Looking to the future, the ECO is proposed to take only $125,000-250,000$ households out of fuel poverty by 2023 (DECC, 2012a) 'when the number of households in fuel poverty is 20-40 times this figure' and could rise sharply due to welfare cuts (Rosenow and Eyre, 2012). This falls someway short of the UK Government's statutory obligation to eradicate fuel poverty by 2016 (DTI, 2001). In 2012 the Government-commissioned Fuel Poverty Review calculated that Green Deal and ECO 'would be expected to increase fuel poverty' (Hills, 2012, p. 112). Meanwhile cuts to local authority budgets have removed some of the key support mechanisms to help those on low-incomes access grants. Coordinated local intervention remains a missing middle in energy and low-carbon policy due to local government cuts and a subsidy regime for decentralised energy that is mainly directed at firms and households. In some areas the gap is being partially filled by a growing community and not-for-profit energy movement (Bulkeley and Kern, 2013) but this is a fraction of what could be achieved through a fully supported strategy of local energy restructuring.

\section{Mixed messages in national energy policy}

In its much delayed energy bill the Government has refused to commit to "decarbonising" the UK's power generation sector by 2030, a move backed by Liberal Democrats but opposed by George Osborne. Conflicts over renewable commitments in the bill have led George Osborne to refer to Parliamentary climate change campaigners as the 'environmental Taliban' (Clark, 2010). The bill has also been delayed because of continued wrangling with the private developers of new nuclear power plants over guaranteed prices for future electricity generation. These long term contracts are designed to share the initial costs of building the reactors over the life time of the plant but have been criticised as a 'hidden' subsidy for nuclear generation at the expense of renewables. Investment has been put on hold as developers and investors wait for clarity in the energy bill and it is difficult to avoid the conclusion that looking to private sector and capital markets to underwrite energy policy 'massively ramp up regulatory risk and the consequent cost of capital' (Porritt, 2011: 22). Meanwhile, energy policy is rendered even more uncertain by the possibility of exploiting shale gas reserves and the quick fix it offers for future UK energy security. Underwritten by the promise of generous tax breaks, the Government's enthusiastic supporting for fracking further undermines the business case for secure investment in renewables. As the Committee on Climate Change have made clear, 'shale gas, like other forms of gas, cannot be regarded as a low-carbon fuel source' (CCC, 2013: 10). 
By 2013 there was evidence that investment in UK renewable energy had fallen to a four year low due to contradictory messages coming from government and a lack of clarity over future policy (Brady and Morrison, 2013). The UK's CO2 emissions increased in 2012 despite the recession and there is concern that current policy gaps will lead to a shortfall in the investment and infrastructure required to meet future reduction targets (Harvey, 2013). Overall sales in the UK 'low carbon and environmental goods and services sector' (LCEGS) have continued to increase by over £5 billion per year, the growth in employment between 2009 and 2011 was not continued into 2011/12. The number of companies in the sector has also declined since 2010 (BIS, 2012). Expansion of the LCEGS sector as low-carbon policy looks to have been thrown off course by hostility to renewables, the rolling back of state investment and patchy support for eco-industries. There is now considerable divergence on renewable energy and low-carbon policy within the UK nations with Scotland demonstrating the economic, social and environmental benefits of proactive government support for renewable energy and carbon reduction (Ellis et al., 2013). If anything, those on the right of the Conservative Party have become more vociferous in their opposition to alternative energy, and more outspoken in voicing doubts over climate change science.

\section{Looking back and looking forward}

In the 2013 mid-term review David Cameron reasserted the pledge to be the greenest Government ever. Given the patchy performance of previous governments this might well turn out to be true, but it is a hard argument to sustain given the rolling-back of key aspects of environmental regulation and the stalling of low-carbon policy. As Porritt (2011: 5) has argued, there are positives, but the 'bad and positively ugly' continue 'to outweigh the good.' Environmental regulation might be expected to come under pressure in a recession. Yet environmental policy has suffered particularly from the Coalition Government's narrow growth agenda and its flip-flopping on renewable energy. The capacity for environmental governance has certainly been weakened by budget cuts at national and sub-national levels and the dismantling of regional institutions. Faced with severe budget cuts local governments have been forced to strip out their environment, sustainability and planning resources.

It remains to be seen whether these functions will be built up again as the economy recovers. Moreover, commitments to carbon reduction sit uneasily with the consumption-based growth model that continues to form the basis of economic policy. Economic recovery has come to depend on more spending and more development, with environmental regulation watered down if it threatens to get in the way. There is growing concern that UK carbon reduction is more than offset by continuing growth in consumption-based emissions from imported goods (CCC, 2013). It is perhaps curious that the potential for significant growth and job creation through the green economy has not been constrained because of hostility to renewables and the ideological framing of environmental regulation as a constraint on business.

The balance of power on environmental policy within the Coalition Government undoubtedly shifted after Chris Huhne's resignation in 2012 removed the sole environmental champion with any clout. David Cameron and Nick Clegg have been silent on issues of environmental policy, doing little to balance the antienvironmentalism expressed by George Osborne, Eric Pickles and other ministers. Looking forward it is difficult to see where a change of direction might come from within the Coalition Government in the absence of an environmental champion. If anything, those on the right of the Conservative party have become more vociferous in their opposition to alternative energy, and more outspoken in voicing doubts over climate 
change science. The Labour opposition has not had much to offer in response, suggesting that the environment is currently a somewhat peripheral political concern for the main political parties and voters; and is likely to remain so unless some external shock to the system can repoliticise the environmental debate - some sort of energy crisis perhaps? Public opposition to fracking or nuclear power generation? Climate change? In the meantime, the environmental challenge continues to be passed on to future governments and future generations.

*Correspondence Address: Aidan While, Department of Town and Regional Planning, University of Sheffield, Sheffield S10 2TN. Email: a.h.while@sheffield.ac.uk

\section{References}

BIS (2013) Low Carbon Environmental Goods and Services (LCEGS): Report for 2011/12. London: Department of Business Innovation and Skills.

Brady, B. and Morrison, S. (2013) Investment in green energy falls to four-year low. The Independent, 2 June, available at: http://www.independent.co.uk/environment/ green-living/investment-in-green-energy-falls-to-fouryear-low-8640849.html

Bulkeley, H.A. and Betsill, M.M. (2013) Revisiting the urban politics of climate change. Environmental Politics, 22, 136-154.

Clark, P. (2012) Minister rounds on 'environmental Taliban'. Financial Times, 3 January, available at: http://www.ft.com/cms/s/0/f0aa4d08-2d9f-11e1-b5bf00144feabdc0.html\#axzz2fLzceHBw

Committee on Climate Change (2013) Reducing the UK's Carbon Footprint and Managing Competitiveness Risks. London: CCC.

Eadson, W., Gilbertson, J. and Walshaw, A. (2013) Attitudes and Perceptions of the Green Deal amongst Private Sector Landlords in Rotherham. Sheffield: CRESR, Sheffield Hallam University.

DCLG (Department of Communities and Local Government) (2011) Pickles and Hammond to end war on motorists, DCLG press release, available at: https://www.gov.uk/government/news/pickles-and-hammond-to-end-the-war-onmotorists

DCLG (2012) National Planning Policy Framework. London: DCLG.

DECC (2011) The Green Deal and Energy Company Obligation. Consultation document. London: Department of Energy and Climate Change.

DECC (2012a) Annual Report on Fuel Poverty Statistics 2012. London: Department of Energy and Climate Change.

DECC (2012b) Final Stage Impact Assessment for the Green Deal and Energy Company Obligation. London: Department of Energy and Climate Change.

DEFRA (Department of Environment, Food and Rural Affairs) (2005) The UK Government Sustainable Development Strategy. London: TSO.

DTI (2001) The UK Fuel Poverty Strategy. London: Department of Trade and Industry.

Department for Transport (DfT) (2013) New measures announced to support the uptake of plug-in vehicles, press release, available at: https://www.gov.uk/government/news/new-measures-announced-to-support-theuptake-of-plug-in-vehicles

Ellis, G., Cowell, R., Sherry-Brennan, F., Strachan, P. A. and Toke, D. (2013) Planning, energy and devolution in the UK. Town Planning Review, 84, 3, 397-410.

Harvey, F. (2011) Autumn statement: George Osborne slams 'costly' green policies', The Guardian, 29 November, available at: http://www.theguardian.com/uk/2011/nov/29/autumn-statement-georgeosborne-green-policies 
Harvey, F. (2012) UK cuts feed-in tariff for solar panels, The Guardian, 1 August, available at: http://www.theguardian.com/environment/2012/aug/01/solarpanel-feed-in-tariff-cut

Harvey, F. (2013) UK 'could miss carbon emissions targets in 2020s'. The Guardian, available at: http://www.theguardian.com/environment/2013/jun/26/uk-misscarbon-emissions-targets

Hills, J. (2012) Getting the Measure of Fuel Poverty. Final Report of the Fuel Poverty Review. London: DECC.

Owens, S. and Cowell, R. (2010) Land and Limits: Interpreting Sustainability in the Planning Process. London: Routledge.

Porritt, J. (2012) The Greenest Government Ever: One Year on A Report to Friends of the Earth, available at: http://www.foe.co.uk/resource/reports/greenest gvt ever.pdf

Randerson, J. (2010) Cameron: I want coalition to be the 'greenest government ever'

The Guardian, 14th May, available at: http://www.theguardian.com/environment/ 2010/may/14/cameron-wants-greenest-government-ever

Rosenow, J. and Eyre, N. (2012) The Green Deal and the Energy Company Obligation will it work?, paper presented at the 9th BIEE Academic Conference 'European Energy in a Challenging World: The impact of emerging markets', St John's College, Oxford, available at: http://eng.janrosenow.com/uploads/4/7/1/2 $\angle 4712328 /$ rosenow-eyre-2012-the-green-deal-and-the-energy-companyobligation.pdf

Rotherham, I. (2010) Environment, economy and community: responding to future environmental change with reducing public sector resources. People, Place and Policy, 4, 1, 33-37.

Shankleman, S. (2013) Green deal: just 133 households have signed up for energy efficiency scheme. The Guardian, 20 August, available at: http://www.theguardian.com/environment/2013/aug/20/green-dealhouseholds-energy-efficiency

Vaughan, A. and Harvey, F. (2013) No UK households have completed green deal process, figures show, The Guardian, available at: http://www.theguardian.com/environment/2013/jun/27/green-deal-energyefficiency

While, A., Jonas, A. E. G. and Gibbs, D. (2010) From sustainable development to carbon control: eco-state restructuring and the politics of urban and regional development. Transactions of the Institute of British Geographers, 35, 1, 76-93.

While, A. (2012) Resisting the Growth Clamp. Planning Theory and Practice, 13, 4, 503506. 